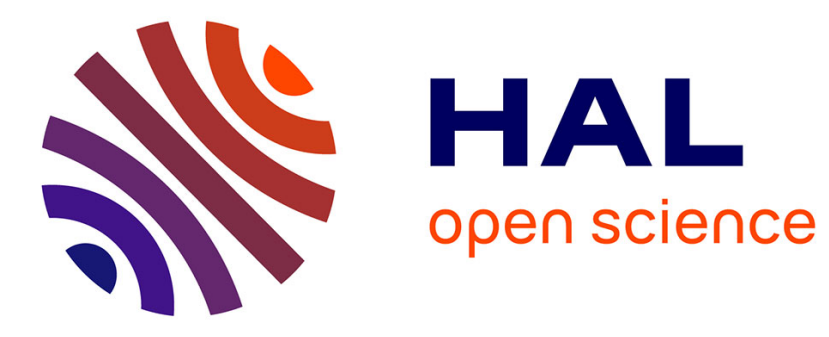

\title{
Tutorial: Service-Oriented Architecture (SOA) Development for Serious Games
}

\author{
Maira B. Carvalho, Jun Hu, Francesco Bellotti, Alessandro De Gloria, \\ Matthias Rauterberg
}

\section{> To cite this version:}

Maira B. Carvalho, Jun Hu, Francesco Bellotti, Alessandro De Gloria, Matthias Rauterberg. Tutorial: Service-Oriented Architecture (SOA) Development for Serious Games. 14th International Conference on Entertainment Computing (ICEC), Sep 2015, Trondheim, Norway. pp.578-580, 10.1007/978-3319-24589-8_61. hal-01758448

\section{HAL Id: hal-01758448 \\ https://hal.inria.fr/hal-01758448}

Submitted on 4 Apr 2018

HAL is a multi-disciplinary open access archive for the deposit and dissemination of scientific research documents, whether they are published or not. The documents may come from teaching and research institutions in France or abroad, or from public or private research centers.
L'archive ouverte pluridisciplinaire HAL, est destinée au dépôt et à la diffusion de documents scientifiques de niveau recherche, publiés ou non, émanant des établissements d'enseignement et de recherche français ou étrangers, des laboratoires publics ou privés.

\section{(c)(1)}

Distributed under a Creative Commons Attribution| 4.0 International License 


\title{
Tutorial: Service-oriented architecture (SOA) development for Serious Games
}

\author{
Maira B. Carvalho ${ }^{1,2}$, Jun $\mathrm{Hu}^{1}$, Francesco Bellotti ${ }^{2}$, Alessandro De Gloria ${ }^{2}$, and \\ Matthias Rauterberg ${ }^{1}$ \\ 1 Eindhoven University of Technology, Netherlands \\ \{m.brandao.carvalho, J.Hu, G.W.M.Rauterberg\}@tue.nl \\ ${ }^{2}$ University of Genoa, Italy \\ \{franz, adg\}@elios.unige.it
}

\begin{abstract}
This tutorial aims to introduce the benefits of applying a service-oriented architecture (SOA) approach to serious games developers. For that end, we propose a hands-on session in which we will provide information on state-of-the-art services for serious games and guide developers in rethinking one of their existing games or game ideas using our SOA framework for serious games.
\end{abstract}

\section{Introduction}

Serious games are typically conceived as one-of-a-kind products fully customized to meet specific learning requirements. This leads to high costs, long production processes and low reusability of the final product and its components, which are all factors that hinder large scale deployment of serious games [4]. The SOA approach has been described as a desirable and beneficial solution for the field, enabling serious games developers to reduce costs and time to market, while enabling flexibility in the development and reuse of software parts [2].

In a previous work [3], we proposed the first steps of a SOA framework to support reusability of serious game components, using elements from the Activity Theory-based Model for Serious Games (ATMSG) [1]. The framework aims to facilitate the serious game development process and to increase the overall quality of the process and of the final product. This is achieved by encouraging the use of interoperability standards and proposing a consistent structure across game components.

However, migrating to a SOA approach for serious games development can have a relatively high learning curve. It involves time and costs to refactor the code, and it can result in increased complexity in testing. For this reason, it is important that developers get acquainted with ways to minimize costs and perform quality assurance. It is also desirable that they are encouraged to identify opportunities to reuse existing components and to share knowledge and best practices.

Given the benefits, but also the added complexity of applying SOA for serious games, we propose this tutorial as a forum for serious games developers to better 
understand what such a migration represents and which opportunities for reuse there are, so that they are able to make informed decisions on the suitability of SOA for their practice.

\section{Intended audience and schedule}

The tutorial targets serious game developers and designers, and particularly participants who have ongoing projects or ideas that could be converted into a service-oriented architecture.

This is a half-day tutorial. The schedule is detailed below.

\section{Welcome (15min)}

Content (60min) We will briefly discuss the benefits of using a service-oriented architecture in the development of serious games, drawing on previous successful experiences [2]. We will then present our SOA framework for serious games. The framework is focused on providing a toolbox of reusable components that are relevant for the development of educational serious games within different genres and domains, with particular emphasis in assessment and adaptivity. It also offers recommendations on which development standards can be employed by developers to maximize compatibility with other existing components. Finally, we will introduce a list of existing services, free and otherwise, that currently can be used by developers in their own projects.

\section{Break (15min)}

Hands-on session (120min) The second part of the tutorial will be a practical one: we will guide the participants in applying the structure of the framework to one of their own games or game ideas. We will help them identify which changes would be needed to convert their games to a SOA architecture. We will provide suggestions of requirements and evaluation metrics to help developers determine if these services are suitable to the scale and scope of their projects. This session will also allow them to identify if there are any components in common between their projects which are not yet available as services, and which could benefit from shared development efforts.

Evaluation (30min) The last part of the tutorial will be a short evaluation of the framework and of the tutorial. We will collect the participants impressions on the framework and discuss their views on the applicability of the framework in different projects.

\section{Expected outcomes}

At the end of the tutorial, participants will have a clear roadmap of what is needed to convert their serious game or game idea to a SOA architecture. This will include an indication of which components of the game could be reused from readily available services, and which ones would have to be developed from scratch. Participants will be able to identify shared needs and possibly establish collaborations to develop these common components, to the benefit of all involved. 
We also expect to improve the SOA framework itself, by collecting the participants' evaluation of the framework quality, relevance and applicability in their own practice. Furthermore, we will be able to gauge which components would be most useful for a larger number of serious games developers, which in turn will be an indication to the serious games community of relevant topics for future research and development.

\section{Acknowledgment}

This work was supported in part by the Erasmus Mundus Joint Doctorate in Interactive and Cognitive Environments, which is funded by the EACEA Agency of the European Commission under EMJD ICE FPA n 2010-0012.

\section{References}

[1] Carvalho, M.B., Bellotti, F., Berta, R., De Gloria, A., Islas Sedano, C., Baalsrud Hauge, J., Hu, J., Rauterberg, M.: An activity theory-based model for serious games analysis and conceptual design. Computers \& Education 87, 166-181 (2015)

[2] Carvalho, M.B., Bellotti, F., Berta, R., Gloria, A.D., Gazzarata, G., Hu, J., Kickmeier-Rust, M.: A case study on service-oriented architecture for serious games. Entertainment Computing 6, 1 - 10 (2015)

[3] Carvalho, M.B., Bellotti, F., Hu, J., Baalsrud Hauge, J., Berta, R., De Gloria, A., Rauterberg, M.: Towards a service oriented architecture framework for educational serious games. In: Proceedings of the 15th IEEE International Conference on Advanced Learning Technologies (ICALT2015). Hualien, Taiwan (July 6-9 2015)

[4] Hauge, J.B., Stanescu, I., Carvalho, M.B., Lim, T., Arnab, S.: Serious games mechanics and opportunities for reuse. In: 11th eLearning and Software for Education Conference (eLSE 2015). Bucharest, Romania (2015) 